\title{
THE USE OF WATERMELON RIND FLOUR AS STABILIZER FOR REDUCED FAT MAYONNAISE
}

\author{
${ }^{1)}$ Herly Evanuarini, ${ }^{1)}$ Dedes Amertaningtyas, ${ }^{1)}$ Dicky Tri Utama, ${ }^{1)}$ Alief Rahmania Safitri \\ 1) Animal Product Technology Department, Faculty of Animal Science, Universitas Brawijaya, Jl. Veteran, \\ Ketawanggede, Kec. Lowokwaru, Kota Malang, Jawa Timur Indonesia 65145 \\ Email: herlyfptub@ub.ac.id
}

Submitted 19 October 2020; Accepted 30 October 2020

\begin{abstract}
Reduced fat mayonnaise is a mayonnaise that reduces some oil to reduced fat content, but reduced fat mayonnaise has a disavantages. A decrease in the oil phase which can affect the stability of the mayonnaise emulsion. One alternative is the addition of watermelon rind flour to increase the quality of mayonnaise. The purpose of this study was to determine the quality of mayonnaise with the addition of watermelon rind flour as stabilizer. The method used was experimental design using a completely randomized design. The treatment were the addition of watermelon rind flour as much as $2 \%, 4 \%, 6 \%$ and control as a comparison. Data were analyzed by analysis of variance and continued with UJBD. The results showed that the addition of watermelon rind flour gave highly significant effect on emulsion stability and moisture content, had a significant effect on $\mathrm{pH}$ and did not gave significant effect on sensory evaluation of mayonnaise. This study concluded that the addition of $6 \%$ watermelon rind flour as stabilizer produces good quality mayonnaise.
\end{abstract}

Keywords: Reduced fat mayonnaise; stabilizer; watermelon rind flour 


\section{INTRODUCTION}

Mayonnaise is a popular sauce that is widely used as a food complement. Mayonnaise has a distinctive sour aroma and a pale white color. As the food industry develops, mayonnaise is currently the food of choice, but because of its oil content which is too high and has a lot of calories. Currently, the most popular type of mayonnaise is full fat. The types of mayonnaise also vary depending on the oil content. Full fat mayonnaise has an oil content of more than $70 \%$ while reduced fat mayonnaise has an oil content of less than 70\%. According to Lee, et al. (2013) stated that reduced fat mayonnaise is made by replacing vegetable oil with other ingredients that can improve the quality of mayonnaise both physicochemically and organoleptically. Mayonnaise product development continues to be encouraged to achieve mayonnaise that is beneficial to the human body. Therefore, the reduced fat type of mayonnaise has been developed with the addition of other ingredients that can improve its physical, chemical and organoleptic quality. Reduced fat mayonnaise has its drawbacks, including the level of consistency and liquid mayonnaise texture due to the lack of emulsifying agent and oil as the dispersion phase.

Watermelon is a tropical fruit that has a water content of about $91 \%$ and $6 \%$ carbohydrates. Watermelon is characterized by its dark green and light green striped rind. Watermelon consists of 3 main parts, namely the outer exocarp of watermelon or green outer rind, endocarp and mesocarp, which is part of the inner rind which is greenish-white and the thickness also differs depending on the fruit species and the inside is called the flesh (Saragih, et al. 2017). Effendi and Wardatun's research (2012) states that a watermelon weight of $5.2 \mathrm{~kg}$ can produce $3.1 \mathrm{~L}$ of watermelon juice and $2.2 \mathrm{~kg}$ of watermelon rind. Watermelon rind which has the potential to become waste can be used as watermelon rind powder for additional food ingredients.

Watermelon rind flour contains enzymes, minerals, vitamin $\mathrm{C}$, citrulline and pectin (Triandini, et al. 2014). The nutritional content of watermelon albedo is water content $(10.61 \%)$, ash content (13.09\%), fat content $(2.44 \%)$ protein content $(11.17 \%)$ and carbohydrate content of $(56.00 \%)$ (Hoque and Iqbal, 2015). Watermelon's proximate albedo content is mostly carbohydrates. The most common carbohydrate found is pectin. Pectin is a type of carbohydrate that can act as a gel making agent, thickening agent, stability agent and emulsion agent (Dranca and Oroian, 2018).

Reduced fat mayonnaise requires another thickening agent such as gum or a fat substitute to maintain its quality. Therefore, watermelon rind waste can be used in the form of flour which will be added to mayonnaise. This study aims to improve physicochemical and sensory evaluation properties and observe changes in emulsion droplets using the main material, namely reduced fat mayonnaise with the addition of watermelon rind flour which has a different percentage for each treatment.

\section{MATERIAL AND METHODS}

\section{Material}

The research material used was mayonnaise made from soybean oil $(70 \%$ (P0), 50\% (P1, P2, P3)), egg yolk (20\%), vinegar $(5 \%)$, sugar $(3 \%)$, salt $(1 \%)$, ground
*Corresponding author:

Herly Evanuarini

Email: herlyfptub@ub.ac.id

Animal Product Technology Department, Faculty of Animal Science, Universitas Brawijaya, Jl. Veteran, Ketawanggede, Kec. Lowokwaru, Kota Malang, Jawa Timur Indonesia 65145

\section{How to cite:}

Evanuarini, H., Amertaningtyas, D., Utama, D. T., \& Safitri, A. R. (2020). The Use of Watermelon Rind Flour as Stabilizer for Reduced Fat Mayonnaise. Jurnal Ilmu dan Teknologi Hasil Ternak, 15 (3), 172-182 
white pepper $(0.5 \%)$ and mustard $(0.5 \%)$. The treatment used was the addition of watermelon rind flour according to the required treatment. Research materials for variable testing include distilled water, $\mathrm{pH} 4$ buffer and $\mathrm{pH} 7$ buffer. The research tools used include analytical scales, $\mathrm{pH}$ meters, beaker glasses, measuring cups, centrifuges, ovens, excicators, weigh bottles, stationery, and eclipse microscopes. equipped with a nikon camera. While the tools for making mayonnaise include a mixer, analytical scale, basin and solet.

\section{Methods}

The research method used was an experimental method with a completely randomized design using 4 treatments and 4 replications. These treatments are:

$\mathrm{P} 0=$ mayonnaise control

$\mathrm{P} 1=$ mayonnaise with the addition of $2 \%$ watermelon rind flour and $50 \%$ oil.

$\mathrm{P} 2=$ mayonnaise with the addition of $4 \%$ watermelon rind flour and $50 \%$ oil.

P3 = mayonnaise with the addition of $6 \%$ watermelon rind flour and $50 \%$ oil.

\section{Watermelon Rind Flour}

Watermelon rind flour from fresh red watermelon (Citrullus lanatus). Watermelon rind is separated and washed thoroughly. The outer shell (the green part) is removed. The white or albedo part is cut about $2 \mathrm{~cm}$. The albedo of watermelon rind is dried using the oven for $5 \mathrm{~d}$ at a temperature of $600 \mathrm{C}$. Albedo dry watermelon is ground with a drymill and then sifted with a 100 mesh sieve. Watermelon rind flour is ready to use.

\section{Mayonnaise Sampling}

Mayonnaise samples production following the procedure of Evanuarini, et al. (2016). The mayonnaise tools and ingredients are prepared. Stir together salt, sugar, pepper and mustard. Then add a third of the egg yolk to a pale yellow color. Alternately, add oil and vinegar to make an emulsion. Mayonnaise is stored in the container for $24 \mathrm{~h}$. Mayonnaise is ready for testing.

\section{Testing Procedure \\ 1. $\mathbf{p H}$}

Mayonnaise $\mathrm{pH}$ testing using a $\mathrm{pH}$ meter (AOAC, 2005). The $\mathrm{pH}$ test begins with the preparation of a sample of $2 \mathrm{~g}$ of mayonnaise and then stored in a container or beaker glass. The mayonnaise sample was dissolved using $20 \mathrm{ml}$ of distilled water. The sample was stirred until homogeneous. Prepare a $\mathrm{pH} 4$ buffer, a $\mathrm{pH} 7$ buffer and distilled water for standardization fluids. The standardized $\mathrm{pH}$ meter is inserted into the sample, then the results listed on the instrument are recorded.

\section{Emulsion Stability}

The sample was weighed as much as $5 \mathrm{~g}$ and then put it in a centrifuge tube. Add $2 \mathrm{ml}$ of oil. Samples were centrifuged for $15 \mathrm{~min}$ at $3000 \mathrm{rpm}$. Weigh the separate oil then reduce it by $2 \mathrm{ml}$. Enter into the calculation formula;

$$
\% \text { emulsion stability }=\frac{\text { initial sample weigh }}{\text { final sample weigh }} \times 100 \%
$$

\section{Moisture Content}

Testing the moisture content using the gravimetric method (AOAC, 2005). Testing the moisture content begins with the oven for $1 \mathrm{~h}$ with a temperature of $105^{\circ} \mathrm{C}$. Remove the weigh bottle and apply for $15 \mathrm{~min}$. Sample preparation was $3 \mathrm{gr}$ and recorded as (A). Weigh the weigh bottles and note the weight.
Add the weight of the weigh bottle and the mayonnaise sample and record it as B. Put the weigh bottle containing the sample in the oven for $3 \mathrm{~h}$ and the temperature is $105^{\circ} \mathrm{C}$. Remove the weigh bottle and put it in the excicator for $15 \mathrm{~min}$. Weigh the weigh bottle and record as $\mathrm{C}$. Calculate the percentage of water content using the following formula: 


$$
\% \text { moisture content }=\frac{(B-A)}{(B-C)} \times 100 \%
$$

\section{Sensory Evaluation}

Sensory testing uses hedonic parameters (Susrini, 2005). The panelists used were 5 semi-trained panelists. The method of testing is to prepare an sensory test worksheet and a mayonnaise sample. Panelists were asked to give an assessment score after tasting, feeling, smelling and considering the overall acceptance of the mayonnaise sample.

\section{Emulsion droplets}

Emulsion droplet observation aims to determine the droplet size contained in the mayonnaise sample. Observation of droplets using an eclipse microscope equipped with a Nikon camera.

The method of observation is by reviewing the sample on the glass object glass as thin as possible and then covering it with a glass cover, observing it with a magnification of $400 \times$ then measuring the droplet size. Take pictures and document them.

\section{Analysis Data}

The data obtained were analyzed using analysis of variance or ANOVA. The data is calculated using the help of Microsoft Excel. If there is a significant difference then continued with Duncan's Multiple Range Test (DMRT).

\section{RESULT AND DISCUSSION}

\section{pH}

The results of the analysis of variance showed that the $\mathrm{pH}$ value of mayonnaise was significantly different $(\mathrm{P}<0.05)$. The mean value of $\mathrm{pH}$ of mayonnaise with the addition of watermelon rind flour can be seen in Table 1.

Table 1. Mean value of $\mathrm{pH}$ of mayonnaise with the addition of watermelon rind flour

\begin{tabular}{cc}
\hline Treatments & $\mathrm{pH} \pm \mathrm{SD}$ \\
\hline P0 & $4.89 \pm 0.02^{\mathrm{a}}$ \\
P1 & $4.97 \pm 0.03^{\mathrm{ab}}$ \\
P2 & $4.98 \pm 0.06^{\mathrm{ab}}$ \\
P3 & $5.03 \pm 0.05^{\mathrm{b}}$ \\
\hline
\end{tabular}

Information: ${ }^{a}, b, c, d$, different superscripts in the same column show significant differences $(\mathrm{P}<0.05)$

The mean $\mathrm{pH}$ value of mayonnaise ranges from 4.89-5.03. Treatment $3(\mathrm{P} 3)$ is the treatment that has the highest $\mathrm{pH}$ value (5.03) with the addition of $6 \%$ watermelon rind flour. Treatment 1 (P1) was the treatment with the lowest value (4.97) with the addition of $2 \%$ watermelon rind flour. The $\mathrm{pH}$ value is the potential value of hydrogen.

This shows how acidic a product is. Watermelon rind flour has a $\mathrm{pH}$ value of 5.2. According to research by Megawati, et al. (2017) stated that watermelon albedo has a $\mathrm{pH}$ value of 5.72. There is no significant difference between the $\mathrm{pH}$ value of watermelon rind flour between Megawati's opinion and the research results.

The more watermelon rind flour is added, the mayonnaise's $\mathrm{pH}$ value will increase. In addition to the $\mathrm{pH}$ of watermelon rind flour, which has an alkaline $\mathrm{pH}$ value compared to the $\mathrm{pH}$ of mayonnaise, the control treatment was 4.89. The $\mathrm{pH}$ of mayonnaise with the addition of watermelon rind flour as much as 6\% provides a good $\mathrm{pH}$ value. According to Triandini, et al (2014) the $\mathrm{H}+$ ion in acidic solutions can break the protoprotein bonds from the albedo cell walls of watermelon rind and can bind pectin molecules so that 
they can bind water. The structure of mayonnaise can significantly affect the $\mathrm{pH}$ of the mayonnaise (Fernandesa and Mellado, 2018). If the $\mathrm{pH}$ value is high, the $\mathrm{H}+$ ion will be few and if the $\mathrm{pH}$ value is low, the $\mathrm{H}+$ ion will increase (Febriningrum, 2013). The addition of a stabilizer such as banana peel also produces a $\mathrm{pH}$ value between 4.43-4.78 (Evanuarini and Susilo, 2020)

\section{Emulsion Stability}

The analysis of variance showed that the stability of the mayonnaise emulsion was significantly different $(P<0.01)$. The emulsion stability of the mayonnaise with the addition of watermelon rind flour can be seen in Table 2. The mayonnaise emulsion stability ranged from 81.98 to $97.79 \%$. Treatment 3 (P3) was the treatment that had the highest emulsion stability $(87.05 \%)$ with the addition of $6 \%$ watermelon rind flour. Treatment 1 (P1) was the treatment with the lowest value $(81.98 \%)$ with the addition of $2 \%$ watermelon rind flour.

Emulsion stability is an indicator of the stability of an emulsion product in which the water phase and oil phase can be measured properly. Emulsion instability can lead to coalescence. Coalescence can be avoided by avoiding the emulsion droplets close together so they do not converge. Emulsion instability can be caused by lack of a stabilizer to reduce the face tension between the oil phase and the water phase (Sangthawan and Anprung, 2014). The use of a higher oil will result in good emulsion stability, but if the amount of oil is reduced, the emulsion stability is affected (Evanuarini, et al. 2019).

Table 2. Average Stability of Mayonnaise Emulsion with Addition of Watermelon Rind Flour

\begin{tabular}{cc}
\hline Tratments & Emulsion Stability (\%) \pm SD \\
\hline P0 & $97.79 \pm 0.87^{\mathrm{c}}$ \\
P1 & $81.98 \pm 0.65^{\mathrm{a}}$ \\
P2 & $85.51 \pm 0.64^{\mathrm{b}}$ \\
P3 & $87.05 \pm 0.82^{\mathrm{b}}$ \\
\hline
\end{tabular}

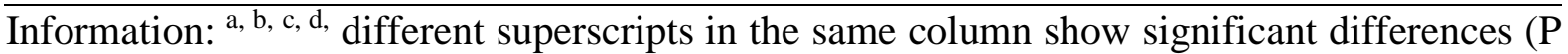
$<0.05)$

Watermelon rind flour as a stabilizer can be used to stabilize the emulsion. The use of banana peel flour stabilizer can also provide high emulsion stability and does not break the emulsion stability (Evanuarini and Susilo, 2020). This is also in accordance with the opinion of Hutapea, et al. (2016) prevention of unwanted physicochemical changes can use a stabilizer. So that if the addition of watermelon rind flour is more, the emulsion stability will be more stable and not easily broken. It can be concluded that the addition of $6 \%$ watermelon rind flour provides good emulsion stability for reduced fat mayonnaise.

\section{Moisture content}

The results of the analysis of variance showed that the moisture content of mayonnaise was significantly different $(\mathrm{P}$
$<0.01)$. The moisture content of mayonnaise with the addition of watermelon rind flour can be seen in Table 3 .

The mean value of moisture content of mayonnaise ranged from 15.34-19.28\%. Treatment 1 (P1) was the treatment that had the highest moisture content value $(17.63 \%)$ with the addition of $2 \%$ watermelon rind flour. Treatment 3 (P3) was the treatment with the lowest value $(15.34 \%)$ with the addition of $6 \%$ watermelon rind flour. The more watermelon rind flour is added, the less moisture content will be.

This is because the watermelon rind flour absorbs water easily. According to research by Zubairu, et al. (2018) proximate analysis of watermelon rind flour in the form of moisture content of $1.1 \%$ and dry weight of $98.8 \%$. The more watermelon rind flour is added, the greater the potential for water 
absorption in the mayonnaise product. This is in accordance with the opinion of Romdhane, et al. (2017) which states that watermelon rind can capture $2 \mathrm{~g}$ of water / $\mathrm{g}$ of water and can also bind fat as much as $4 \mathrm{~g}$ of oil / gram. This water absorption is also influenced by the chemical content contained in watermelon rind flour, including protein and fiber polysaccharides and other compounds that can bind the compounds in the product (Putri, et al. 2016).

Table 3. The mean value of Mayonnaise Moisture Content with the Addition of Watermelon Rind Flour

\begin{tabular}{cc}
\hline Treatments & Moisture Content $(\%) \pm$ SD \\
\hline P0 & $19.28 \pm 0.30^{\mathrm{c}}$ \\
P1 & $17.63 \pm 0.54^{\mathrm{b}}$ \\
P2 & $16.92 \pm 0.89^{\mathrm{b}}$ \\
P3 & $15.34 \pm 0.28^{\mathrm{a}}$ \\
\hline
\end{tabular}

Information: $\mathrm{a}, \mathrm{b}, \mathrm{c}, \mathrm{d}$, different superscripts in the same column show hihgly significant differences $(\mathrm{P}<0.01)$

The moisture content in mayonnaise is only found in the water phase in the form of vinegar, the water content of egg yolks and watermelon rind flour which is only a small percentage of water. Water is an important phase in emulsion products because water can balance the fat and protein products (Amin, et al. 2014). Research on mayonnaise with the addition of banana peel flour as a stabilizer resulted in a moisture content of around 14.16-22.62\% (Evanuarini and Susilo, 2020). The addition of $6 \%$ watermelon peel flour can reduce water content and is the best treatment for this parameter.

\section{Sensory Evaluation}

Mayonnaise with the addition of watermelon rind flour can be assessed for its organoleptic quality. This is to assess the acceptance of a product in accordance with the senses of taste, smell, sight and touch. The organoleptic value of mayonnaise can be seen in Table 4.

Table 4. Score of Organoleptic Value of Mayonnaise with Addition of Watermelon Rind Flour

\begin{tabular}{cccccc}
\hline Tratments & Texsture & Aroma & Color & Taste & $\begin{array}{c}\text { Overall } \\
\text { Acceptance }\end{array}$ \\
\cline { 2 - 5 } P0 & $4.00 \pm 0.73$ & $3.95 \pm 0.51$ & $4.40 \pm 0.50$ & $3.90 \pm 0.45$ & $4.00 \pm 0.86$ \\
P1 & $3.80 \pm 0.62$ & $4.00 \pm 0.32$ & $4.10 \pm 0.55$ & $4.05 \pm 0.22$ & $4.40 \pm 0.82$ \\
P2 & $4.05 \pm 0.51$ & $4.15 \pm 0.75$ & $3.85 \pm 0.59$ & $4.15 \pm 0.59$ & $4.25 \pm 0.55$ \\
P3 & $4.10 \pm 0.55$ & $4.20 \pm 0.52$ & $3.65 \pm 0.49$ & $4.20 \pm 0.41$ & $4.20 \pm 0.77$ \\
\hline
\end{tabular}

\section{Mayonnaise Texture}

The sensory mean value of texture was 3.80 - 4.10. Mayonnaise with the addition of watermelon rind flour as much as $6 \%(\mathrm{P} 3)$ gave the highest score mean value of texture (4.10) and mayonnaise with the addition of $2 \%$ watermelon rind flour (P1) had the lowest score of texture (3.80). This is because watermelon rind flour has a high carbohydrate content, especially sugar. Sugar can help shape the texture, so the more watermelon rind flour you add to the mayonnaise, the thicker the texture will be. The oil greatly affects the texture of the mayonnaise. Gaikwad, et al. (2017) oil, which is the main component of fat, greatly affects the rheological and organoleptic characteristics of the final product. The rough texture is caused by the presence of large granules or large sand crystals (Asih and Mujdalipah, 2018), so the more watermelon rind flour is added, the better and thicker the texture will be. 


\section{Mayonnaise Aroma}

The score mean values of aroma were 3.95 - 4.20. Mayonnaise with the addition of watermelon rind flour as much as $6 \%(\mathrm{P} 3)$ had the highest score aroma value (4.20) and mayonnaise with the addition of $2 \%$ watermelon rind flour (P1) had the lowest score aroma (4.00). The control treatment had a strong sour aroma derived from vinegar and mustard. This is in accordance with the opinion of Karas, et al. (2002) which states that the mayonnaise standard has a strong sour flavor and aroma. The addition of watermelon rind flour also affects physically. The sour mayonnaise scent of vinegar and mustrad and the fishy smell of egg yolks will disappear because it is covered by the aroma of watermelon rind flour. Research by Ibrahim, et al. (2016) showed that watermelon rind flour can reduce ammonia odor by around 1,235$1,237 \mathrm{mg} / \mathrm{L}$. Other research on mayonnaise with the addition of banana peel flour produces a balanced aroma with mayonnaise and can be accepted by panelists (Evanuarini and Susilo, 2020). The addition of $6 \%$ watermelon rind flour gave the panelists a welcome aroma.

\section{Mayonnaise color}

The score mean values of the colors were 3.65 - 4.40. Mayonnaise with the addition of $2 \%$ watermelon rind flour (P1) had the highest score color value (4.10) and mayonnaise with the addition of watermelon rind flour as much as $6 \%(\mathrm{P} 3)$ had the lowest score color (3.65). Watermelon rind or watermelon albedo which has a yellowish white color. The brownish color that comes from the watermelon rind flour is due to the treatment of the semnagka rind flour which is made by drying the watermelon rind to reduce the moisture content, resulting in the browning process.

This is in accordance with the opinion of Mardiah (1996) that this pigment is triggered by the presence of oxygen into an oxidation reaction with the help of a phenol or polyphenol oxidase enzyme catalyst then phenol compounds become quinones and polymerized into brown melaniadin pigments. Colorants or dyes are found in plant cell walls because cell walls contain hemicellulose, cellulose and pectin which are used as barrier to intracellular substances (Sangthawan and Anprung, 2014). Color is one of the indicators for consumers to choose a product (Abu Salem and Abou Arab, 2008). The mayonnaise research with the addition of banana peel flour resulted in a darker color of around 3.35-4.35 (Evanuarini and Susilo, 2020).

\section{Mayonnaise flavor}

The organoleptic mean values were 3.90 - 4.20. Mayonnaise with the addition of watermelon rind flour as much as $6 \%(\mathrm{P} 3)$ had the highest average taste value (4.20) and mayonnaise with the addition of $2 \%$ watermelon rind flour (P1) had the lowest taste (4.05). Mayonnaise control has a strong sour taste standard (Karas, et al. 2002). The addition of more watermelon rind flour can provide a sweet and stable taste. The addition of flour which functions as a stabilizer can help stabilize the mayonnaise taste. The addition of starch to the stabilizer can stabilize the mayonnaise taste (Lee, et al. 2013). The addition of $6 \%$ watermelon rind flour gave the panelists a mayonnaise taste.

\section{Overall Acceptance of Mayonnaise}

The mean sensory values of the overall acceptance were $4.00-4.40$. Mayonnaise with the addition of watermelon rind flour as much as $2 \%(\mathrm{P} 1)$ had the highest average overall acceptance value (4.40) and mayonnaise with the addition of watermelon rind flour as much as $6 \%(\mathrm{P} 3)$ had the lowest overall acceptance value (4.20) . Overall watermelon rind flour greatly affects the color, texture, taste and aroma of the mayonnaise. The more the watermelon rind flour is added, the darker the mayonnaise will be, but the sweeter the taste, the sour aroma also disappears. The mayonnaise will be thicker and denser. Karas, et al. (2002) using a stabilizer in mayonnaise, which aims 
to form mayonnaise in order to form a mayonnaise that is similar to full fat both physically and organoleptically. Overall, the panelists liked the mayonnaise with the addition of watermelon rind flour as much as $6 \%$ giving a good effect.

\section{Emulsion droplets}

The droplet size of mayonnaise emulsion with the addition of watermelon rind flour can be seen in Table 5. The average droplet size of mayonnaise emulsion with the addition of watermelon rind flour was 1.10 - 15.80. The more watermelon rind flour is added, the emulsion droplets will be smaller and denser.

A cross-sectional image of the mayonnaise emulsion droplet with the addition of watermelon rind flour can be seen in the Figure below. Figure 1 shows that treatment 1 (P1) has a larger droplet size than treatment $3(\mathrm{P} 3)$. This is because the more watermelon rind flour is added, the dense and compact the droplet size will be. This can be seen in Figure 1 in treatment 3 (P3).

Table 5. Droplet size of mayonnaise emulsion with the addition of watermelon rind flour

\begin{tabular}{cc}
\hline Tratments & Average Emulsion Droplet Size $(\mu \mathrm{m})$ \\
\hline P0 & $1.90-12.36$ \\
P1 & $1.80-15.80$ \\
P2 & $1.40-13.74$ \\
P3 & $1.10-8.39$ \\
\hline
\end{tabular}

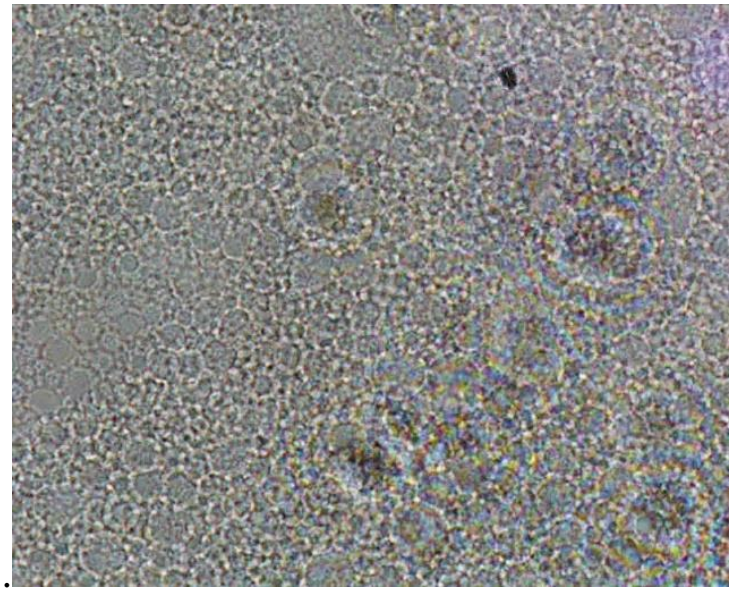

P0

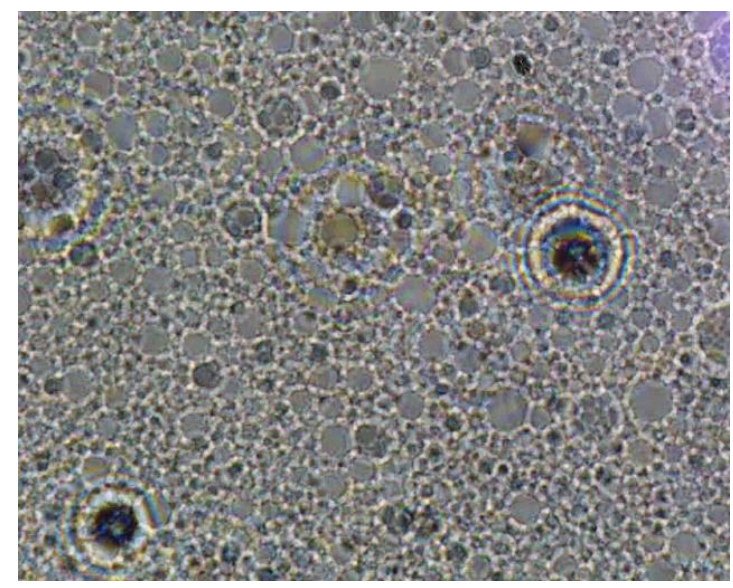

$\mathrm{P} 2$

Figure 1. Droplet of Reduced Fat Mayonnaise Emulsion with Addition of Watermelon Rind

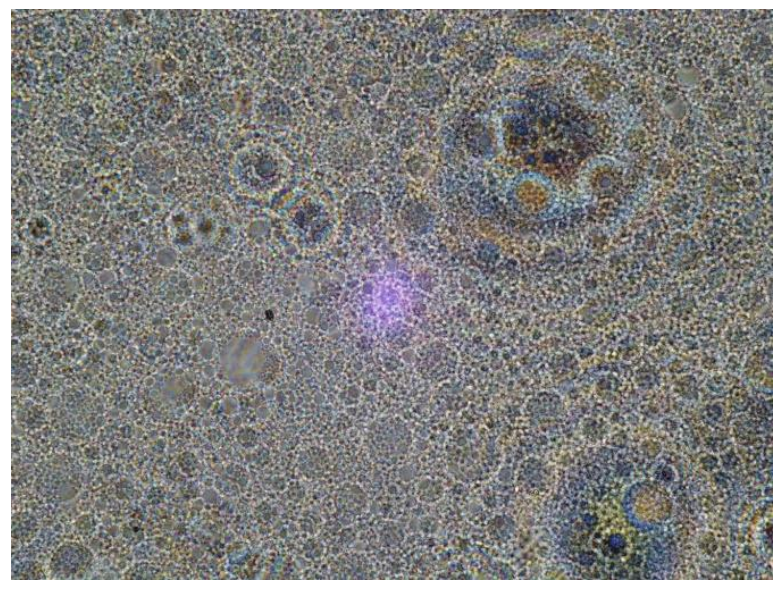

P1

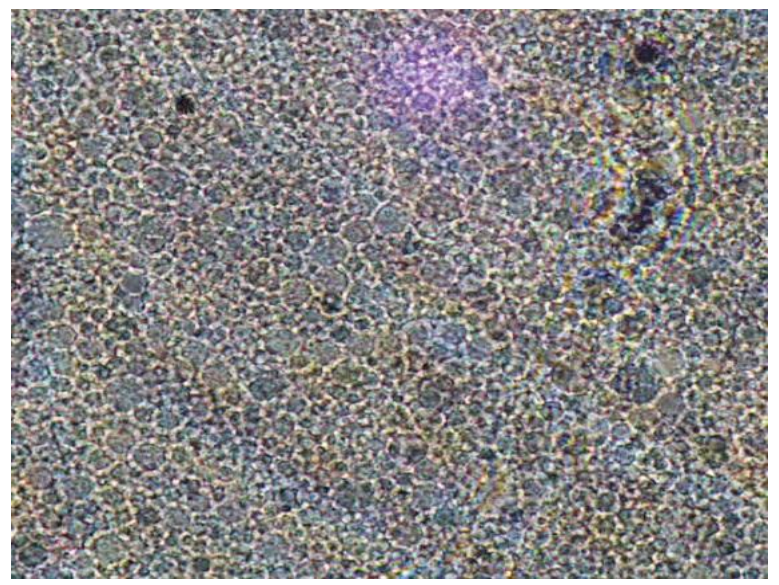
P3 
Smaller droplets and many have a thick texture. Emulsion droplet size affects the texture and viscosity of the mayonnaise. Watermelon rind flour can absorb water to become thicker and denser The distribution of emulsion droplet particles and their various sizes also affects the viscosity of the mayonnaise. According to Song, et al. (2007) with the addition of emulsion stability, viscosity, fat size distribution, concentration and type of emulsifier and distribution ratio. Watermelon rind flour contains a lot of carbohydrates and of course it contains starch. Starch is a polysaccharide that is used as a gelling, thickening and stabilizing agent (Petkowicz, et al. 2017).

Full fat mayonnaise with oil concentrations between $70-80 \%$ has a droplet size of about 1-20 $\mu \mathrm{m}$ or more (Gaikwad, et al 2017). The control treatment has droplets that are very close and dense so that the emulsion droplets cannot move (ElBostany, et al. 2011). Mayonnaise with the addition of porang flour as a stabilizer of 0.3 also produces dense emulsion droplets of various sizes (Evanuarini, et al. 2015). Based on the results of this study, it can be concluded that with the addition of $6 \%$ watermelon rind flour, it provides good droplet observation results.

\section{CONCLUSION}

It can be concluded that the addition of watermelon rind flour as much as $6 \%$ as stabilizer gave the best quality of reduced fat mayonnaise.

\section{REFERENCE}

Abu-Salem, F. M., \& Abou-Arab, A. A. (2008). Chemical, microbiological and sensory evaluation of mayonnaise prepared from ostrich eggs. Grasas y Aceites, 59(4), 352-360. https://doi. org/10.3989/gya.2008.v59.i4.529

Amin, M. H. H., Elbeltagy, A. E., Mustafa, M., \& Khalil, A. H. (2014). Development of low fat mayonnaise containing different types and levels of hydrocolloid gum Sensory optimization of low fat mayonnaise (different oils and gums). Journal of Agroalimentary Processes and Technologies, 20(1), 54-63.

AOAC. (2005). Official Methods of Analysis. AOAC International.

Asih, T. F., \& Mujdalipah, S. (2019). Study of utilization of flesh and banana peel flour to sensory characteristics of ice cream. EDUFORTECH, 4(1), 25-32. https://doi.org/10.17509/edufortech.v $4 \mathrm{i} 1.16347$

Dranca, F., \& Oroian, M. (2018). Extraction, purification and characterization of pectin from alternative sources with potential technological applications. Food Research International, 113, 327-350. https://doi.org/10.1016/j.fo odres.2018.06.065

Effendi, E. M., \& Wardatun, S. (2012). Potensi buah semangka merah (Citrullus vulgaris rubrum) dan sari buah semangka kuning (Citrullus vulgaris flavum) sebagai peluruh batu ginjal kalsium oksalt secara in vitro. Ekologia, 12(1), 6-11.

El-Bostany, A. N., Ahmed, M. G., \& Amany, A. S. (2011). Development of light mayonnaise formula using carbohydrate-based fat replacement. Australian Journal of Basic and Applied Sciences, 5(9), 673-682.

Evanuarini, H, \& Susilo, A. (2020). The quality of low fat mayonnaise using banana peel flour as stabilizer. IOP Conference Series: Earth and Environmental Science, 478, 012091. https://doi.org/10.1088/1755-1315/47 8/1/012091

Evanuarini, H., Nurliyani., Indratiningsih, \& Hastuti, P. (2015). Characteristic of low fat mayonnaise containing porang flour as stabilizer. Pakistan Journal of Nutrition, 14(7), 392-395. https://doi. org/10.3923/pjn.2015.392.395

Evanuarini, H., Nurliyani., Indratiningsih, \& Hastuti, P. (2016). Kestabilan emulsi dan karakteristik sensoris low fat mayonnaise dengan menggunakan 
kefir sebagai emulsifier replacer. Jurnal Ilmu Dan Teknologi Hasil Ternak, 11(2), 53-59.

Evanuarini, H., Nurliyani., Indratiningsih., \& Hastuti, P. (2019). Kestabilan emulsi dan oksidasi low fat mayonnaise menggunakan kefir sebagai alternatif emulsifier. Jurnal Ilmu-Ilmu Peternakan, 29(1), 83-94. https://doi.org/10.21776/ub.jiip.2019. 029.01.10

Farida, S., Ishartani, D., \& Affandi, R. (2016). Pengaruh penambahan gum arab terhadap karakteristik fisik, kimia, dan organoleptik fruit and vegetable leather dari albedo semangka (Citrullus vulgaris Schard.) dan wortel (Daucus carota). Jurnal Teknosains Pangan, 5(4), 20-30.

Febriningrum, P. N. (2013). Pengaruh konsentrasi substrat kulit nanas dan kecepatan pengadukan terhadap pertumbuhan lactobacillus plantarum untuk produksi asam laktat. Jurnal Rekayasa Kimia \& Lingkungan, 9(3), 144-151. https://doi.org/10.23955/rkl. v9i3.784

Gaikwad, M., Syed, H., \& Shinde, D. (2017). To study the physico chemical properties of flavoured mayonnaise. Journal of Pharmacognosy and Phytochemistry, 6(5), 06-09.

Ibrahim, A., Yusof, L., Beddu, N. S., Galasin, N., Lee, P. Y., Lee, R. N. S., \& Zahrim, A. Y. (2016). Adsorption study of Ammonia Nitrogen by watermelon rind. IOP Conference Series: Earth and Environmental Science, 36, 012020. https://doi.org/ 10.1088/1755-1315/36/1/012020

Karas, R., Skvarča, M., \& Žlender, B. (2002). Sensory quality of standard and light mayonnaise during storage. Food Technology and Biotechnology, 40(2), 119-127.

Lee, I., Lee, S., Lee, N., \& Ko, S. (2013). Reduced-fat mayonnaise formulated with gelatinized rice starch and xanthan gum. Cereal Chemistry Journal, 90(1), 29-34. https://doi.org/
10.1094/CCHEM-03-12-0027-R

Megawati, T., \& Setiaries Johan, V. (2017). Pembuatan selai lembaran dari albedo semangka dan terong belanda. FAPERTA, 4(2), 12.

Petkowicz, C. L. O., Vriesmann, L. C., \& Williams, P. A. (2017). Pectins from food waste: Extraction, characterization and properties of watermelon rind pectin. Food Hydrocolloids, 65, 57-67. https://doi. org/10.1016/j.foodhyd.2016.10.040

Prabawati, I., Mustofa, A., \& Wulandari, Y. W. (2020). Pengaruh konsentrasi zat penstabil dan jenis kuning telur terhadap mutu reduced fat mayonnaise. Jurnal Teknologi Dan Industri Pangan, 5(1), 304-311. https://doi.org/10.33061/jitipari.v5i1. 3640

Romdhane, M. Ben, Haddar, A., Ghazala, I., Jeddou, K. Ben, Helbert, C. B., \& Ellouz-Chaabouni, S. (2017). Optimization of polysaccharides extraction from watermelon rinds: Structure, functional and biological activities. Food Chemistry, 216, 355364. https://doi.org/10.1016/j.foodch em.2016.08.056

Sangthawan, S., \& Anprung, P. (2014). Enzymatically depolymerized mangosteen aril pectin as a stabilizer for low cholesterol mayonnaise. International Food Research Journal, 21(3), 963-973.

Santos Fernandesa, S., \& Salas-Mellado, M. de las M. (2018). Effect of oil replacement in mayonnaise by chia (Salvia hispanica L) mucilage. Integrative Food, Nutrition and Metabolism, 5(3), 1-3. https://doi. org/10.15761/IFNM.1000218

Saragih, M. A., Johan, V. S., \& Pato, U. (2017). Penambahan kelopak rosellaterhadap mutu pengaruh penambahan kelopak rosellaterhadap mutu sensori permen jellydari albedo semangka. Jom Faperta Ur, 4(1), 5-9.

Song, E.-S., Kim, E., \& Woo, N.-R.-Y. (2007). Development of low fat 
mayonnaise made with modified starch. Journal of the Korean Society of Food Culture, 22, 254-260.

Susrini. (1994). Metode Pengujian Bahan Makanan Secara Sensori. Fakultas Peternakan Universitas Brawijaya.

Triandini, M., Aslamiah, \& Wicakso, D. R. (2014). Pengambilan pektin dari albedo semangka dengan proses ekstraksi asam. Konversi, 3(1), 1-9. Zubairu, A., Gimba, A. S. B., Mamza, W. J., \& Highina, B. K. (2018). Proximate analysis of dry watermelon (Citrullus lanatus) rind and seed powder. Journal of Scientific and Engineering Research, 5(3), 473-478. 